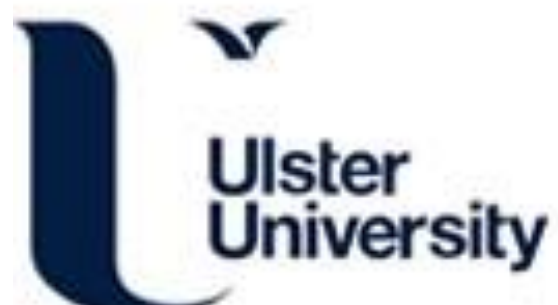

Production of Xylitol by the Thermotolerant Kluyveromyces marxianus IMB Strains

Mueller, M., Wilkins, M., \& Banat, I. (2011). Production of Xylitol by the Thermotolerant Kluyveromyces marxianus IMB Strains. Journal of Bioprocessing and Biotechniques, 1:102e. https://doi.org/10.4172/2155$9821.1000102 \mathrm{e}$

Link to publication record in Ulster University Research Portal

\section{Published in:}

Journal of Bioprocessing and Biotechniques

Publication Status:

Published (in print/issue): 01/09/2011

DOI:

10.4172/2155-9821.1000102e

\section{Document Version}

Publisher's PDF, also known as Version of record

\section{General rights}

Copyright for the publications made accessible via Ulster University's Research Portal is retained by the author(s) and / or other copyright owners and it is a condition of accessing these publications that users recognise and abide by the legal requirements associated with these rights.

\section{Take down policy}

The Research Portal is Ulster University's institutional repository that provides access to Ulster's research outputs. Every effort has been made to ensure that content in the Research Portal does not infringe any person's rights, or applicable UK laws. If you discover content in the Research Portal that you believe breaches copyright or violates any law, please contact pure-support@ulster.ac.uk. 


\title{
Production of Xylitol by the Thermotolerant Kluyveromyces marxianus IMB Strains
}

\author{
Michael Mueller ${ }^{1}$, Mark R. Wilkins ${ }^{1 *}$ and Ibrahim M. Banat ${ }^{2}$
}

${ }^{1}$ Department of Biosystems an Agricultural Engineering, Oklahoma State University, 111 Agricultural Hall, Stillwater, Oklahoma, USA 74078

${ }^{2}$ School of Biomedical Sciences, University of Ulster, Coleraine, BT52 1SA, Northern Ireland, UK

\begin{abstract}
Xylitol is a fermentation product of xylose that can be used as a sweetener by diabetics. Five novel Kluyveromyces marxianus yeast strains, IMB1, IMB2, IMB3, IMB4 and IMB5, have shown the ability to grow on xylose and produce xylitol. In comparison to chemical synthetic xylitol production, biological production can be more cost effective since no expensive metal catalysts and high temperatures are needed. The five $\mathrm{K}$. marxianus IMB strains were tested at temperatures ranging from $25^{\circ} \mathrm{C}$ to $45^{\circ} \mathrm{C}$ with xylose as the sole carbon source. IMB2 was found to be the best xylitol producer among the IMB yeast. Product yields $\left(\mathrm{Y}_{\mathrm{P} / \mathrm{S}}\right)$ up to $0.90 \mathrm{~g} / \mathrm{g}$ at $40^{\circ} \mathrm{C}$ with $1.0 \mathrm{~g} / \mathrm{l}$ initial cell mass and $50 \mathrm{~g} / \mathrm{l}$ initial xylose concentration were observed for IMB2.
\end{abstract}

\section{Keywords}

Bioproducts; Sweeteners; Xylose; Fermentation

\section{Introduction}

Xylitol is a by-product of xylose fermentation and is a sugar alcohol [1]. Xylitol contains $40 \%$ fewer calories than sucrose on a mass basis and has similar sweetness [2]. It is odorless and has no aftertaste. Researchers have found that xylitol prevents dental cavities [3] and has an anti-ketonic [4] and an anti-infection effect [5]. Xylitol is produced by catalytic hydrogenation of xylose [6], which is costly and needs harsh reaction conditions. Biological xylitol production could be more cost effective, since no expensive catalysts are needed and the reaction takes place at ambient temperatures. Yeasts are well-known for their potential in industrial applications. Candida mogii was found to produce xylitol with a high yield $\left(\mathrm{Y}_{\mathrm{P} / \mathrm{S}}=0.62\right)$ [7]. The researchers observed that initial xylose concentration, co-factor regeneration and oxygen transfer were key factors for xylitol production [7]. Debaryomyces hansenii was observed to produce xylitol with product yields from $0.76 \mathrm{~g} / \mathrm{g}$ to 0.78 $\mathrm{g} / \mathrm{g}$ at $30^{\circ} \mathrm{C}$ and $200 \mathrm{rpm}$ using Erlenmeyer flasks [8-10]. In a study using corn cob hemicellulose hydrolyzate, xylitol yields from xylose up to $0.73 \mathrm{~g} / \mathrm{g}$ were observed using Candida tropicalis W103 at $35^{\circ} \mathrm{C}$ [11].

In this study five K. marxianus strains, IMB1, IMB2, IMB3, IMB4, and IMB5, were investigated for their ability to produce xylitol from xylose. The yeast were isolated from an Indian distillery and showed the ability to grow at high temperatures using glucose $\left(52^{\circ} \mathrm{C}\right)$ and ferment xylose as a carbon source at temperatures up to $45^{\circ} \mathrm{C}[12,13]$. The thermotolerant nature of the IMB yeasts allows them to be used in tropical locations while reducing the need for fermenter cooling systems. The optimum growth rates of IMB strains were found at $40^{\circ} \mathrm{C}$ and a value of $0.93 \mathrm{~h}^{-1}$ with glucose as substrate [13]. Wilkins et al. carried out tests by using $K$. marxianus IMB2, IMB4, and IMB5 with different $\mathrm{pH}$ values and different temperatures under anaerobic conditions [14]. IMB5 had the greatest xylitol production at $40^{\circ} \mathrm{C}$ and an initial $\mathrm{pH}$ of 4.5 with a value of $1.33 \mathrm{~g} / \mathrm{l}$ and a product yield of $0.25 \mathrm{~g} / \mathrm{g}$ [14].

The enzymes necessary for xylose fermentation, xylose reductase (XR) and xylitol dehydrogenase (XD) must be activated by the presence of xylose. XR and XD are not available during glucose fermentation [15]. Xylose is reduced to xylitol, catalyzed by XR, and further oxidized to xylulose, catalyzed by XD. Xylulose enters the pentose phosphate cycle and is eventually converted to ethanol [16-18]. Some yeast tend to produce mainly xylitol and others ethanol. This is caused by different co-factor regeneration systems. It is known that yeast like Pichia stipitis, which produce ethanol, can use NADH as a co-factor for XR; whereas, xylitol producers primarily use NADPH [19]. XD uses $\mathrm{NAD}^{+}$as a cofactor in all xylose fermenting yeast [19]. In ethanol producing yeast, a regeneration cycle for $\mathrm{NADH}$ is established and xylulose production is favored. In xylitol producing yeast, NADPH is regenerated with the subsequent pentose phosphate cycle, but NADH accumulates and XD is inhibited, resulting in xylitol accumulation. This process only occurs under anaerobic or microaerobic conditions since $\mathrm{NAD}^{+}$is regenerated by oxygen [19].

In this study all five $K$. marxianus IMB yeast strains were screened at $25,30,35,40$, and $45^{\circ} \mathrm{C}$ at microaerobic conditions to ascertain their ability to produce xylitol using xylose as the sole carbon source. Growth rates, xylitol and ethanol concentrations, conversion efficiencies, as well as product and biomass yields were determined. Also, XR and XD activities at $40^{\circ} \mathrm{C}$ for all IMB strains were analyzed. In addition, the effect of initial substrate concentration on fermentation was analyzed.

\section{Materials and Methods}

\section{Organisms}

The organisms used were five $K$. marxianus yeast strains called IMB1, IMB2, IMB3, IMB4, and IMB5. These yeast were first discovered in an Indian distillery and are maintained at the University of Ulster [13]. Cultures were stored on slants of solid media in a refrigerator. The slant media contained $3 \mathrm{~g} / \mathrm{l}$ yeast extract, $3 \mathrm{~g} / \mathrm{l}$ malt extract, $5 \mathrm{~g} / \mathrm{l}$ peptone, $20 \mathrm{~g} / \mathrm{l}$ xylose, and $20 \mathrm{~g} / \mathrm{l}$ agar.

*Corresponding author: Mark R. Wilkins Department of Biosystems and Agricultural Engineering, Oklahoma State University, 111 Agricultural Hall, Stillwater, OK 74078, Tel: 405.744.8416, Fax: 405.744.6059; E-mail: mark. wilkins@okstate.edu

Received July 29, 2011; Accepted July 29, 2011; Published July 30, 2011

Citation: Mueller M, Wilkins MR, Banat IM (2011) Production of Xylitol by the Thermotolerant Kluyveromyces marxianus IMB Strains. J Bioprocess Biotechniq 1:102e doi: 10.4172/2155-9821.1000102e

Copyright: (C) 2011 Mueller M, et al. This is an open-access article distributed under the terms of the Creative Commons Attribution License, which permits unrestricted use, distribution, and reproduction in any medium, provided the original author and source are credited. 


\section{Preparation of seed culture}

Prior to use all glassware, stoppers, and other equipment used in direct contact with the organisms were sterilized by autoclaving at $121^{\circ} \mathrm{C}$ for $30 \mathrm{~min}$. Cell transfer and sample collection were done in a biological safety cabinet (Coy, Grasslake, MI, USA). A seed culture was prepared in media containing $10 \mathrm{~g} / \mathrm{l}$ yeast extract, $20 \mathrm{~g} / \mathrm{l}$ peptone and $20 \mathrm{~g} / \mathrm{l} \mathrm{xy}$ lose (YPX media). Sterilization of media was achieved by using a filter assembly with a $0.45 \mu \mathrm{m}$ filter. A loopful of cells for each K. marxianus IMB strain was added to $100 \mathrm{ml}$ of YPX media in $250 \mathrm{ml}$ baffled flasks. The flasks were closed with a stopper containing a filter to allow air exchange and prevent microbial contamination (Bug Stopper, Whatman Inc., Florham Park, NJ, USA). The seed culture was incubated for $18 \mathrm{~h}$ at $45^{\circ} \mathrm{C}$. Aeration was achieved by shaking at $220 \mathrm{rpm}$ by using an incubator with an orbital shaker (MaxQ Mini 4450, Barnstead International, Dubuque, IA, USA).

\section{IMB yeast screening}

The inoculum media contained $10 \mathrm{~g} / \mathrm{l}$ yeast extract, $20 \mathrm{~g} / \mathrm{l}$ peptone, and $20 \mathrm{~g} / \mathrm{l}$ glucose. The media was sterilized with a filter assembly using a $0.45 \mu \mathrm{m}$ filter. Baffled flasks $(250 \mathrm{ml})$ were filled with $100 \mathrm{ml}$ of inoculum media, inoculated with $1 \mathrm{ml}$ of seed culture containing one of the K. marxianus strains and closed with the stopper previously described. Conditions were the same as for the seed culture $\left(45^{\circ} \mathrm{C}, 18\right.$ hours, 220 $\mathrm{rpm}$ ). To maintain $\mathrm{pH}$ during fermentation, a $50 \mathrm{mM}$ sodium citrate buffer at pH 5.5 was used to dissolve the media components. The fer-

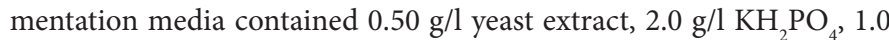
$\mathrm{g} / \mathrm{l}\left(\mathrm{NH}_{4}\right)_{2} \mathrm{SO}_{4}, 1.0 \mathrm{~g} / \mathrm{l} \mathrm{MgSO}_{4}{ }^{\star} 7 \mathrm{H}_{2} \mathrm{O}, 0.10 \mathrm{~g} / \mathrm{l} \mathrm{MnSO}_{4}$, and $20.0 \mathrm{~g} / \mathrm{l}$ xylose [12].

After $18 \mathrm{~h}$ the optical density (OD) of the inocula at a wave length of $660 \mathrm{~nm}$ was determined using a UV visible spectrophotometer (Varian, Palo Alto, CA, USA). An initial OD of 0.5 (representing 0.14 g dry cells/l) was set for each fermentation culture by mixing centrifuged ( $5 \mathrm{~min}, 4^{\circ} \mathrm{C}$, and 6,100 g) (Sorvall Legend RT, Thermo Scientific, Waltham, MA, USA), DI water washed cells from the inocula with 10 $\mathrm{ml}$ DI water. Ten $\mathrm{ml}$ inoculum was added to $90 \mathrm{ml}$ fermentation media [20]. The flasks were enclosed with the previously described stoppers. Growth conditions were 25, 30, 35, 40 or $45^{\circ} \mathrm{C}$ with shaking at $100 \mathrm{rpm}$. Constant temperature and shaking was achieved by using the incubator/shaker. According to Yablochkova et al. [19], shaking at $100 \mathrm{rpm}$ on an orbital shaker like the one used in this study resulted in an oxygen transfer rate of $5 \mathrm{mmol} /\left(\mathrm{l}^{*} \mathrm{~h}\right)$ and led to a microaerobic environment for ethanol and xylitol production from xylose. For the IMB screening experiment, samples were taken at $0,1,2,3,4,5,6,24,48,72,96,120$, and $144 \mathrm{~h}$.

OD was measured via the UV-Vis spectrophotometer and samples were filtered through a $0.2 \mu \mathrm{m}$ filter from Fisher Scientific (Pittsburgh, PA., USA). The permeate was used for high performance liquid chromatography (HPLC) analysis, which is described below. Every IMB strain was tested twice at each temperature.

\section{Effect of initial cell mass concentration on xylitol production}

To investigate the effect of different initial cell mass concentrations, a test with IMB2 at $40^{\circ} \mathrm{C}$ and high xylose concentration was performed. The inoculum was prepared the same as the inoculum for the screening experiment except the incubation temperature was $40^{\circ} \mathrm{C}$ and xylose was the carbohydrate source. Xylose was used since it was found that xylitol production was better for cells produced from medium containing xylose as opposed to cells produced from medium containing glucose (data not shown). The fermentation media was prepared as the fermentation media for the screening test containing a xylose concentration of $50 \mathrm{~g} / \mathrm{l}$. The fermentation media was inoculated with cells to achieve 0.5 , 1.0 , and $1.5 \mathrm{~g} / \mathrm{l}$ of dry cell mass using the same procedure for cell harvest and wash as described above [20]. Samples were taken at 0, 6, 12, 24, $48,72,96,120$ and 144 hours and analyzed via HPLC as described later.

\section{HPLC analysis}

Concentrations of xylose, xylitol, ethanol, acetic acid, and glycerol were analyzed on a HPX-87H column (Bio-Rad, Sunnyvale, CA, USA). The eluent was $0.01 \mathrm{~N} \mathrm{H}_{2} \mathrm{SO}_{4}$ with a flow rate of $0.6 \mathrm{ml} / \mathrm{min}$ at $60^{\circ} \mathrm{C}$, and a refractive index detector (1100 Series, Agilent, Santa Clara, CA, USA) was used for detection [21].

\section{Assay for XR and XD Activity}

The procedure was modified from the one described by Smiley and Bolen [15]. All IMB yeast strains were grown in YPX medium containing $10 \mathrm{~g} / \mathrm{l}$ yeast extract, $20 \mathrm{~g} / \mathrm{l}$ peptone, and $20 \mathrm{~g} / \mathrm{l}$ xylose for $18 \mathrm{~h}$ at $40^{\circ} \mathrm{C}$ and $220 \mathrm{rpm}$. The cells were centrifuged at $4^{\circ} \mathrm{C}$ and $6,100 \mathrm{~g}$ for $10 \mathrm{~min}$. After the liquid was discarded, the cells were washed with DI water and centrifuged again under the same conditions. The cells were re-suspended with $1 \mathrm{ml} 0.1 \mathrm{M}$ potassium phosphate buffer per gram cell pellet. The cells were stored until usage at $-18^{\circ} \mathrm{C}$. After the cells were thawed, $0.3 \mathrm{ml}$ of $0.1 \mathrm{M} \mathrm{2-mercaptoethanol} \mathrm{per} \mathrm{ml}$ cell suspension was added. A cell disruption was achieved via sonication (Misonix Sonicator 3000, Misonix Incorporated, Farmingdale, NY, USA) for $35 \mathrm{~min}$ in $10 \mathrm{sec}$ pulses with $10 \mathrm{sec}$ intervals on level 5 . The mass was centrifuged at 16,060 g for $20 \mathrm{~min}$ (AccuSpin Micro, Fisher Scientific, Pittsburgh, PA, USA). The following solutions were added into a $1 \mathrm{ml}$ spectrophotometer cuvette: $0.05 \mathrm{ml}$ of $1.0 \mathrm{M}$ potassium phosphate buffer $\mathrm{pH}$ 7.4, $0.1 \mathrm{ml}$ of $0.1 \mathrm{M}$ 2-mercaptoethanol, $0.1 \mathrm{ml}$ of $0.5 \mathrm{M}$ D-xylose, 0.1 $\mathrm{ml}$ of cell free extract, and $0.55 \mathrm{ml}$ DI water. At time zero $0.1 \mathrm{ml}$ of 3.4 mM NADH was added. The absorption was measured in a spectrophotometer (Varian, Palo Alto, CA, USA) at $340 \mathrm{~nm}$ for $6 \mathrm{~min}$. The same procedure was repeated with NADPH as cofactor. NADH and NADPH were purchased from Sigma-Aldrich (St. Louis, MO, USA) and EMD Chemicals (Gibbstown, NJ, USA), respectively.

\section{Statistical analysis}

Two level factorial tests were performed for both the yeast screening and effect of carbohydrate sources tests. Yeast strain and temperature were the independent variables andxylitol concentration was the dependent variable. An analysis of variance was calculated using SAS Release 9.1 (SAS, Carey, NC) and means were separated for each variable by Fisher's protected least significant difference analysis at $95 \%$ confidence level.

\section{Results and Discussion}

\section{IMB Yeast screening}

Table 1 presents the product and substrate yields, maximum xylitol concentrations, conversion efficiencies, and growth rates for each strain at each temperature. Table 2 summarizes the mean xylitol concentration for 72 to $144 \mathrm{~h}$, including p-values for strain, temperature, and the interaction of strain and temperature. Values with the same letter are not significantly different $(\mathrm{p}>0.05)$. The growth rates differed among temperatures. In general the growth rate was highest at $40^{\circ} \mathrm{C}$. At $40^{\circ} \mathrm{C}$ 


\begin{tabular}{|c|c|c|c|c|c|c|}
\hline Temp. $\left[{ }^{\circ} \mathrm{C}\right]$ & IMB & $\begin{array}{l}\text { YP/S } \\
\text { (g xylitol/g } \\
\text { xylose) }\end{array}$ & $\begin{array}{l}\text { YP/X } \\
\text { (g xyiltol/g } \\
\text { cells) }\end{array}$ & CE [\%] & $\begin{array}{l}\text { Maximum } \\
\text { Xylitol } \\
\text { Concen- } \\
\text { tration }\end{array}$ & $\begin{array}{l}\text { Growth } \\
\text { rate }\left[h^{-1}\right]\end{array}$ \\
\hline \multirow[t]{5}{*}{25} & 1 & 0.06 & 0.18 & 3.7 & 0.75 & 0.08 \\
\hline & 2 & 0.09 & 0.26 & 5.8 & 1.18 & 0.08 \\
\hline & 3 & 0.03 & 0.09 & 2.0 & 0.41 & 0.08 \\
\hline & 4 & 0.08 & 0.20 & 5.0 & 1.01 & 0.07 \\
\hline & 5 & 0.18 & 0.68 & 10.3 & 2.09 & 0.07 \\
\hline \multirow[t]{5}{*}{30} & 1 & 0.26 & 1.13 & 18.6 & 3.77 & 0.10 \\
\hline & 2 & 0.15 & 0.54 & 10.1 & 2.05 & 0.11 \\
\hline & 3 & 0.12 & 0.45 & 8.3 & 1.68 & 0.11 \\
\hline & 4 & 0.19 & 0.60 & 13.3 & 2.70 & 0.11 \\
\hline & 5 & 0.17 & 0.61 & 11.5 & 2.33 & 0.10 \\
\hline \multirow[t]{5}{*}{35} & 1 & 0.26 & 1.18 & 24.0 & 4.86 & 0.12 \\
\hline & 2 & 0.26 & 1.18 & 23.6 & 4.78 & 0.13 \\
\hline & 3 & 0.26 & 1.35 & 23.5 & 4.76 & 0.11 \\
\hline & 4 & 0.23 & 0.96 & 20.9 & 4.24 & 0.14 \\
\hline & 5 & 0.24 & 1.24 & 21.8 & 4.42 & 0.12 \\
\hline \multirow[t]{5}{*}{40} & 1 & 0.41 & 3.37 & 35.8 & 7.26 & 0.15 \\
\hline & 2 & 0.42 & 3.42 & 38.8 & 7.86 & 0.16 \\
\hline & 3 & 0.34 & 2.18 & 26.1 & 5.29 & 0.14 \\
\hline & 4 & 0.40 & 2.06 & 30.2 & 6.12 & 0.20 \\
\hline & 5 & 0.32 & 2.27 & 27.3 & 5.53 & 0.16 \\
\hline \multirow[t]{5}{*}{45} & 1 & 0.36 & 3.45 & 27.4 & 5.55 & 0.11 \\
\hline & 2 & 0.42 & 4.18 & 38.1 & 7.72 & 0.12 \\
\hline & 3 & 0.31 & 3.21 & 21.5 & 4.36 & 0.08 \\
\hline & 4 & 0.41 & 3.42 & 33.3 & 6.75 & 0.08 \\
\hline & 5 & 0.29 & 2.76 & 21.8 & 4.42 & 0.09 \\
\hline
\end{tabular}

Table 1: Xylitol yields from xylose and cells (YP/S, YP/X), conversion efficiency (CE) and growth rates of $\mathrm{K}$. marxianus IMB strains at $100 \mathrm{rpm}$ in $250 \mathrm{ml}$ baffled flasks.

\begin{tabular}{|l|l|l|l|l|l|}
\hline Time $(\mathrm{h})$ & & 72 & 96 & 120 & 144 \\
\hline Strain & IMB1 & $2.63^{\mathrm{AB}} \pm 0.47$ & $3.74^{\mathrm{A}} \pm 0.63$ & $4.01^{\mathrm{A}} \pm 0.60$ & $3.37^{\mathrm{A}} \pm 0.48$ \\
\hline & IMB2 & $2.85^{\mathrm{A}} \pm 0.59$ & $3.90^{\mathrm{A}} \pm 0.77$ & $4.10^{\mathrm{A}} \pm 0.75$ & $3.50 \mathrm{~A} \pm 0.61$ \\
\hline & IMB3 & $2.32^{\mathrm{C}} \pm 0.47$ & $2.74^{\mathrm{C}} \pm 0.51$ & $2.58^{\mathrm{C}} \pm 0.49$ & $2.07^{\mathrm{C}} \pm 0.51$ \\
\hline & IMB4 & $2.50 \mathrm{~B}^{\mathrm{C}} \pm 0.52$ & $3.23^{\mathrm{B}} \pm 0.57$ & $3.35^{\mathrm{B}} \pm 0.53$ & $2.86^{\mathrm{B}} \pm 0.55$ \\
\hline & IMB5 & $2.75 \mathrm{AB} \pm 0.43$ & $3.17^{\mathrm{B}} \pm 0.42$ & $3.07^{\mathrm{B}} \pm 0.31$ & $2.63^{\mathrm{B}} \pm 0.35$ \\
\hline Temp $\left({ }^{\circ} \mathrm{C}\right)$ & 25 & $0.73^{\mathrm{A}} \pm 0.14$ & $0.83^{\mathrm{A}} \pm 0.12$ & $0.99^{\mathrm{A}} \pm 0.14$ & $1.09^{\mathrm{A}} \pm 0.17$ \\
\hline & 30 & $1.42^{\mathrm{B}} \pm 0.10$ & $2.04^{\mathrm{B}} \pm 0.17$ & $2.40^{\mathrm{B}} \pm 0.22$ & $2.36^{\mathrm{B}} \pm 0.23$ \\
\hline & 35 & $3.03^{\mathrm{C}} \pm 0.14$ & $4.31^{\mathrm{C}} \pm 0.16$ & $4.57^{\mathrm{C}} \pm 0.16$ & $3.74^{\mathrm{C}} \pm 0.23$ \\
\hline & 40 & $5.71^{\mathrm{E}} \pm 0.12$ & $6.24^{\mathrm{E}} \pm 0.40$ & $4.73^{\mathrm{C}} \pm 0.66$ & $2.42^{\mathrm{B}} \pm 0.72$ \\
\hline & 45 & $3.48^{\mathrm{D}} \pm 0.32$ & $4.80^{\mathrm{D}} \pm 0.44$ & $5.57^{\mathrm{D}} \pm 0.45$ & $5.55^{\mathrm{D}} \pm 0.37$ \\
\hline P values & Strain & 0.0001 & $<.0001$ & $<.0001$ & $<.0001$ \\
\hline & Temp & $<.0001$ & $<.0001$ & $<.0001$ & $<.0001$ \\
\hline & Str. +Temp. & $<.0001$ & $<.0001$ & $<.0001$ & $<.0001$ \\
\hline
\end{tabular}

Table 2: Mean values with standard error of xylitol concentration [g/l] during $K$. marxianus IMB strains screening. Factor strain shows the mean values over all temperatures and factor temperature shows the mean values over all strains. Values with the same letter for each column were not significantly different $(\alpha=0.05)$.

the highest growth rate of $0.2 \mathrm{~h}^{-1}$ was achieved with IMB4 Table 1 . Banat and Marchant [12], who first investigated the IMB strains, found growth rates on xylose at $45^{\circ} \mathrm{C}$ between $0.18 \mathrm{~h}^{-1}$ and $0.26 \mathrm{~h}^{-1}$ for IMB5 and IMB4, respectively. The higher growth rates in their study can be explained by the difference in aeration. In this study, microaerobic conditions were used; whereas, Banat and Marchant [12] determined growth rates for aerobic conditions. Microaerobic condition is defined by aeration with oxygen concentrations below the oxygen concentration of air. Yablochkova et al. [19] determined an oxygen transfer rate of $5 \mathrm{mmol} \mathrm{O}_{2} /\left(\mathrm{l}^{\star} \mathrm{h}\right)$ as microaerobic conditions leading to optimum xylose fermentation. Low growth rates are favorable, since more of the substrate can be used for product formation.

Xylose consumption varied with temperature as well. At $40^{\circ} \mathrm{C}$ all strains consumed almost all xylose; whereas, at all other temperatures xylose remained after $144 \mathrm{~h}$. The highest xylose concentrations remained in the media at $25^{\circ} \mathrm{C}$ with values ranging from $8.2 \mathrm{~g} / \mathrm{l}$ with IMB5 to $6.6 \mathrm{~g} / \mathrm{l}$ with IMB3 (data not shown). Similar characteristics where shown in a previous study that was conducted with IMB2, IMB4, and IMB5 [14]. According to the figures shown in their work, IMB4 did not utilize xylose completely at $45^{\circ} \mathrm{C}$ with a value of about $10 \mathrm{~g} / \mathrm{l}$ after $120 \mathrm{~h}$. In that study it was concluded that IMB4 produced the highest ethanol concentration. However, that study was under anaerobic conditions; whereas, this study was conducted under microaerobic conditions [14].

The IMB yeast showed a greater capability for xylitol production in comparison to ethanol production. Ethanol production was negligible. Temperature has a strong influence on xylitol production with the highest mean concentration at $40^{\circ} \mathrm{C}(6.24 \mathrm{~g} / \mathrm{l}$ after $96 \mathrm{~h})$ and the lowest at $25^{\circ} \mathrm{C}(1.09 \mathrm{~g} / \mathrm{l}$ after $144 \mathrm{~h})$ Table 2 . This is in alignment with the higher xylose utilization at $40^{\circ} \mathrm{C}$. The results indicate the thermotolerant nature of the K. marxianus IMB yeast, which was, to the authors' knowledge, not found in any other publication on xylitol producing yeast. Yeast strain also affected xylitol production. IMB2 had the highest mean maximum xylitol concentration of all strains with the same value at 40 and $45^{\circ} \mathrm{C}(4.1 \mathrm{~g} / \mathrm{l})$, but it was not significantly different than IMB1. The lowest production was achieved by IMB3 with a mean value of $2.74 \mathrm{~g} / \mathrm{l}$ Table 2 .

The greatest xylitol yield from xylose $\left(\mathrm{Y}_{\mathrm{P} / \mathrm{S}}\right)$ and initial cell mass $\left(\mathrm{Y}_{\mathrm{P} / \mathrm{X}}\right)$ was achieved by IMB2 with $0.42 \mathrm{~g}$ xylitol/g xylose and $4.18 \mathrm{~g}$ xylitol/g cells at $45^{\circ} \mathrm{C}$ Table 1 . The highest conversion efficiency (maximum xylitol concentration/theoretical xylitol concentration) was $38.1 \%$. In general, the yeast with the greatest $\mathrm{YP} / \mathrm{S}$ also had the greatest $\mathrm{YP} / \mathrm{X}$. The same was true for the lowest $\mathrm{YP} / \mathrm{S}$ and $\mathrm{YP} / \mathrm{X}$ with the exception of $40^{\circ} \mathrm{C}$, where the lowest $\mathrm{YP} / \mathrm{S}$ and $\mathrm{YP} / \mathrm{X}$ was shown by IMB5 and IMB4, respectively. It should be noted that the xylitol concentration for all IMB strains at $40^{\circ} \mathrm{C}$ decreased rapidly after reaching the maximum concentration (data not shown). At all other temperatures, the maximum xylitol concentrations were observed at the end of fermentation. Within xylose metabolism xylitol is an intermediate that can be further converted to ethanol. Indeed, ethanol concentration increased while xylitol concentration decreased after $96 \mathrm{~h}$ at $40^{\circ} \mathrm{C}$ (data not shown). However, ethanol production was very low with the greatest observed concentration of $1.64 \mathrm{~g} / \mathrm{l}$ by IMB 1 at $40^{\circ} \mathrm{C}$ after $144 \mathrm{~h}$. It can be assumed that the decrease in xylitol concentration is caused by the usage of xylitol for other metabolites and/or cell maintenance.

\section{Effect of initial cell mass concentration on xylitol production}

During the test with three different initial cell mass concentrations, similar cell mass concentrations were observed after $120 \mathrm{~h}$, ranging between 2.22 and $2.45 \mathrm{~g} / \mathrm{l}$ for $1.5 \mathrm{~g} / \mathrm{l}$ and $0.5 \mathrm{~g} / \mathrm{l}$, respectively. Cultures initially containing $0.5 \mathrm{~g} / \mathrm{l}$ and $1.5 \mathrm{~g} / \mathrm{l}$ cell mass showed an increase in cell mass during the last $24 \mathrm{~h}$ (between 120 and $144 \mathrm{~h}$ ) to 3.68 and $2.95 \mathrm{~g} / \mathrm{l}$, respectively Figure 1 . The cultures initially containing $1.0 \mathrm{~g} / \mathrm{l}$ cell mass did not grow in the last $24 \mathrm{~h}$. It can be assumed, that during the 120 $\mathrm{h}$ sampling, the $0.5 \mathrm{~g} / \mathrm{l}$ and $1.5 \mathrm{~g} / \mathrm{l}$ cultures were introduced to higher oxygen concentration, which led to elevated growth rates.

The cultures with 0.5 and $1.5 \mathrm{~g} / \mathrm{l}$ initial cell mass concentration consumed the most xylose after $144 \mathrm{~h}$ with a final xylose concentration of 
Citation: Mueller M, Wilkins MR, Banat IM (2011) Production of Xylitol by the Thermotolerant Kluyveromyces marxianus IMB Strains. J Bioprocess Biotechniq 1:102e doi: 10.4172/2155-9821.1000102e

Page 4 of 5

4.90 and $6.28 \mathrm{~g} / \mathrm{l}$, respectively Figure $1 \mathrm{~A}$. Cultures initially containing $1.0 \mathrm{~g} / \mathrm{l}$ cell mass had a final xylose concentration of $15.3 \mathrm{~g} / \mathrm{l}$.

The highest xylitol concentration for all tests was achieved after $144 \mathrm{~h}$. Cultures initially containing $0.5 \mathrm{~g} / \mathrm{l}$ cell mass produced the highest xylitol concentration with $34.6 \mathrm{~g} / \mathrm{l}$ Figure 1B, which represents an $\mathrm{YP} / \mathrm{S}$ of $0.76 \mathrm{~g} / \mathrm{g}$ Tables 4 and 5 . Cultures initially containing $1.0 \mathrm{~g} / \mathrm{l}$ cell mass produced a lower concentration with $29.9 \mathrm{~g} / \mathrm{l}$ of xylitol, but had a product yield of $0.86 \mathrm{~g} / \mathrm{g}$ since less xylose was used. Cultures initially containing $1.5 \mathrm{~g} / \mathrm{l}$ cell mass produced a xylitol concentration of $30.6 \mathrm{~g} / \mathrm{l}$ and a product yield of $0.70 \mathrm{~g} / \mathrm{g}$. There was no significant dif-
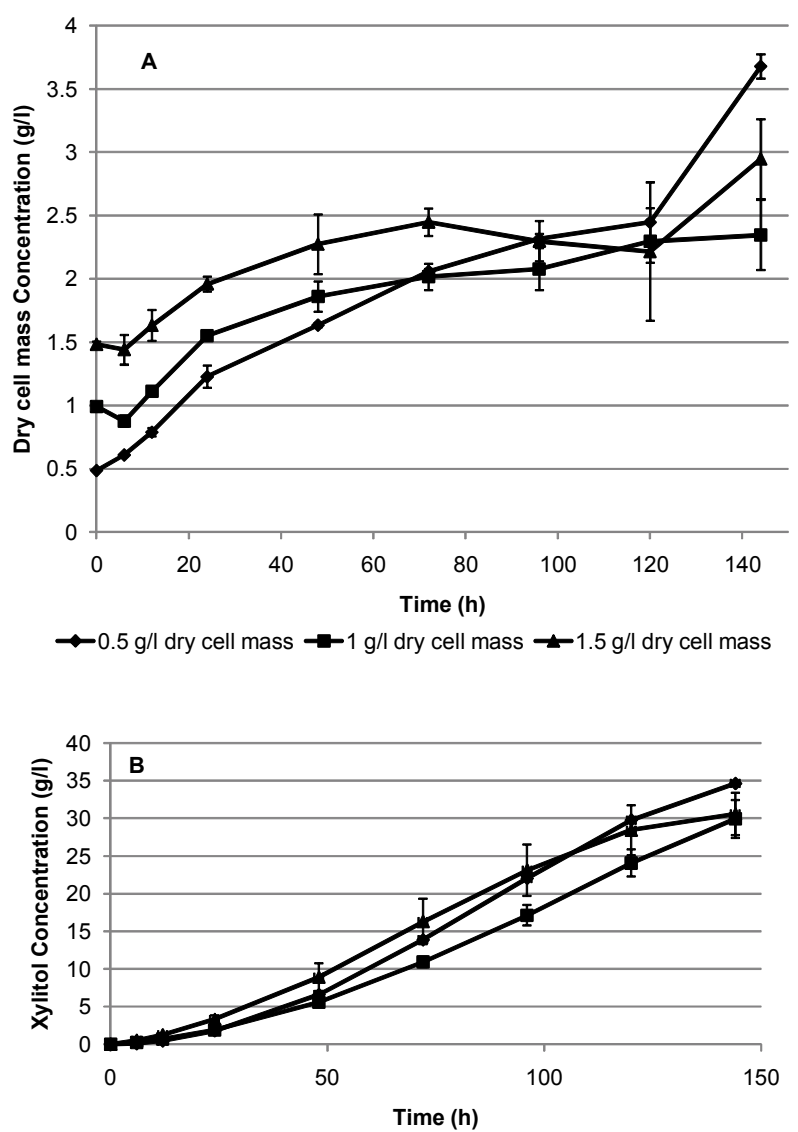

$\rightarrow 0.5 \mathrm{~g} / \mathrm{l}$ initial cell mass $\rightarrow-1.0 \mathrm{~g} / \mathrm{l}$ initial cell mass $\leftarrow 1.5 \mathrm{~g} / \mathrm{l}$ initial cell mass

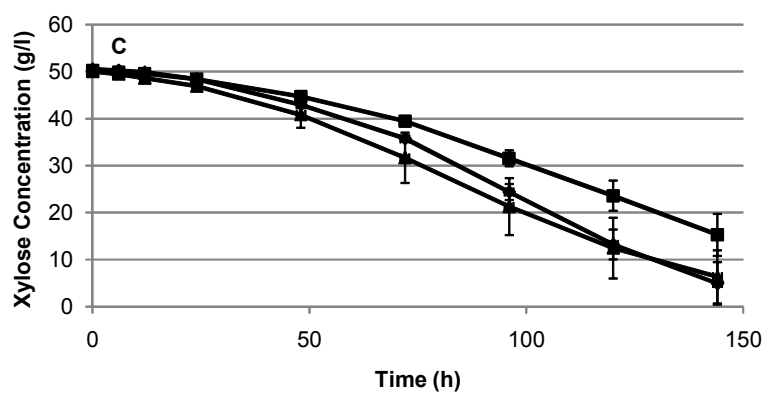

$\rightarrow 0.5 \mathrm{~g} / \mathrm{l}$ initial cell mass $\rightarrow-1.0 \mathrm{~g} / \mathrm{l}$ initial cell mass $\rightarrow 1.5 \mathrm{~g} / \mathrm{l}$ initial cell mass

Figure 1: Dry cell mass concentration $(A)$, xylitol production $(B)$ and xylose concumption (C) by $\mathrm{K}$. marxianus IMB2 at $40^{\circ} \mathrm{C}$ three different initial cell mass concentrations $(0.5,1.0,1.5 \mathrm{~g} / \mathrm{l})$. Error bars represent standard error. ference between the three initial cell mass concentrations in terms of $144 \mathrm{~h}$ xylitol concentration ( $\mathrm{p}>0.05$ ). Comparing YP/S values at 120 $\mathrm{h}$, which excludes the great increase in cell mass in the last $24 \mathrm{~h}$, shows that cultures with $1.0 \mathrm{~g} / \mathrm{l}$ initial cell mass had the highest yield with 0.90 $\mathrm{g} / \mathrm{g}$ compared to 0.80 and $0.76 \mathrm{~g} / \mathrm{g}$ with cultures with $0.5 \mathrm{~g} / \mathrm{l}$ and $1.5 \mathrm{~g} / \mathrm{l}$ initial cell mass, respectively. Xylitol concentrations after $120 \mathrm{~h}$ were different among the initial cell mass concentrations Table 3 . The greatest mean xylitol concentration produced was $29.76 \mathrm{~g} / \mathrm{l}$ by cultures with $0.5 \mathrm{~g} / \mathrm{l}$ initial cell mass.

Cultures with $1.0 \mathrm{~g} / \mathrm{l}$ initial cell mass still had the potential to produce more xylitol after $144 \mathrm{~h}$, since $18 \mathrm{~g} / \mathrm{l}$ of xylose remained in the media. Comparing the YP/X values, $0.5 \mathrm{~g} / \mathrm{l}$ initial cell mass showed the highest yield of $71.16 \mathrm{~g}$ xylitol/g initial dry cell mass after $144 \mathrm{~h}$ Table 4. Cultures initially containing $1.0 \mathrm{~g} / \mathrm{l}$ and $1.5 \mathrm{~g} / \mathrm{l}$ cell mass have lower yields since less xylitol was produced with higher initial cell mass concentrations. The yields are 30.20 and $20.64 \mathrm{~g} / \mathrm{g}$ for $1.0 \mathrm{~g} / \mathrm{l}$ and $1.5 \mathrm{~g} / \mathrm{l}$, respectively Table 4.

Initial substrate and cell mass concentrations have an effect on the xylitol production of the IMB yeast. The yields of all three tests with elevated initial cell mass concentrations are higher than the yields achieved during the IMB screening and the inoculum carbohydrate test. Compared to the literature, the yields achieved with IMB2 at $40^{\circ} \mathrm{C}$ with $50 \mathrm{~g} / \mathrm{l}$ initial substrate concentration and $1.0 \mathrm{~g} / \mathrm{l}$ initial dry dell mass concentration $(0.86 \mathrm{~g} / \mathrm{g})$ are the highest with natural occurring yeast we have found (e.g. D. hansenii with $0.78 \mathrm{~g} / \mathrm{g}$ ) [8], 10]. However, the maximum observed productivity of $0.24 \mathrm{~g} / \mathrm{L} / \mathrm{h}$ is much lower than observed for C. tropicalis W103, which was $1.07 \mathrm{~g} / \mathrm{L} / \mathrm{h}$ [11]. Increased productivity is necessary for utilizing $K$. marxianus IMB2 for industrial xylitol production.

\begin{tabular}{|l|l|l|l|}
\hline Time $(\mathrm{h})$ & & 120 & 144 \\
\hline $\begin{array}{l}\text { Initial cell mass } \\
\text { concentration }[\mathrm{g} / \mathrm{l}]\end{array}$ & 0.5 & $29.76^{\mathrm{A}} \pm 0.19$ & $34.64 \pm 0.20$ \\
\hline & 1.0 & $24.09^{\mathrm{B}} \pm 1.04$ & $29.92 \pm 1.44$ \\
\hline & 1.5 & $28.43^{\mathrm{AB}} \pm 1.92$ & $30.59 \pm 1.62$ \\
\hline P value & Cell mass & 0.0439 & 0.0745 \\
\hline
\end{tabular}

Table 3: Mean values and standard errors for xylitol concentration after 120 and 144 hours with different initial cell mass concentrations $(\alpha=0.05)$. Values with different letters are significant different (t-test (LSD)).

\begin{tabular}{|c|c|c|c|c|c|}
\hline Time [h] & $\begin{array}{c}\text { Cell mass } \\
\text { [g/l] }\end{array}$ & $\begin{array}{c}\text { YP/S } \\
\text { (g xylitol/g } \\
\text { xylose) }\end{array}$ & $\begin{array}{c}\text { YP/X } \\
\text { (g xyiltol/g } \\
\text { initial cells) }\end{array}$ & CE [\%] & $\begin{array}{c}\text { Maximum Xylitol } \\
\text { Concentration [g/l] }\end{array}$ \\
\hline 120 & 0.5 & 0.80 & 61.15 & 58.4 & 29.76 \\
\hline & 1.0 & 0.90 & 24.32 & 47.5 & 24.09 \\
\hline & 1.5 & 0.76 & 19.19 & 56.3 & 28.43 \\
\hline 144 & 0.5 & 0.76 & 71.16 & 67.9 & 34.64 \\
\hline & 1.0 & 0.86 & 30.20 & 58.9 & 29.92 \\
\hline & 1.5 & 0.70 & 20.64 & 60.6 & 30.59 \\
\hline
\end{tabular}

Table 4: Xylitol yields from xylose and cells (YP/S, YP/X), conversion efficiency (CE) and growth rates of IMB2 with different initial cell mass concentrations (Test parameters: $40^{\circ} \mathrm{C}, 100 \mathrm{rpm}$, and $50 \mathrm{~g} / \mathrm{l}$ initial xylose concentration).

\begin{tabular}{|l|l|l|}
\hline \multirow{2}{*}{ Yeast } & \multicolumn{1}{|c|}{ XR activity [IU/ml] } & \multicolumn{1}{c|}{ NADH } \\
\cline { 2 - 3 } & \multicolumn{1}{|c|}{ NADPH } \\
\hline IMB1 & n.d. & 2.85 \\
\hline IMB2 & n.d. & 2.68 \\
\hline IMB3 & n.d. & 0.51 \\
\hline IMB4 & n.d. & 0.26 \\
\hline IMB5 & n.d. & 2.91 \\
\hline
\end{tabular}

Table 5: XR activity of IMB yeast strains at $40^{\circ} \mathrm{C}$ (n.d. = non-detectable). The units are in $\mathrm{IU} / \mathrm{ml}\left(\mu \mathrm{mol}\right.$ of cofactor oxidized / $\left(\mathrm{ml}\right.$ cell free extract $\left.\left.{ }^{*} \mathrm{~min}\right)\right)$. 
Citation: Mueller M, Wilkins MR, Banat IM (2011) Production of Xylitol by the Thermotolerant Kluyveromyces marxianus IMB Strains. J Bioprocess Biotechniq 1:102e doi: 10.4172/2155-9821.1000102e

Page 5 of 5

\section{Determination of XR Activity}

To understand why the IMB yeast produce high amounts of xylitol and low amounts of ethanol, the XR activity of all IMB strains was tested with NADH and NADPH as cofactors. Table 5 lists the activities of $\mathrm{XR}$ in $\mathrm{IU} / \mathrm{ml}$ cell free extract. The resulting XR activities using $\mathrm{NADH}$ versus NADPH support the proposed cofactor imbalance being responsible for high xylitol and low ethanol yields. No activity was detected using NADH as cofactor for all IMB strains. By using NADPH the activity ranged from 0.26 to $2.91 \mathrm{IU} / \mathrm{ml}$. No correlation between XR activities and maximum xylitol concentrations or product yields was established. However, IMB1 and IMB2, which were observed to produce the greatest xylitol concentrations during the yeast screening, had two of the higher activities observed.

NADPH cannot be regenerated with the second step and an imbalance of cofactors is caused by microaerobic conditions in the yeast. This confirms the study by Yablochkova et al. (2004) [20] which presented that $\mathrm{K}$. marxianus has a low xylose reductase activity while using $\mathrm{NADH}$ as a cofactor. The researchers reported $<0.01$ and $0.16 \mu \mathrm{mol} /$ (mg*min) as the activities for XR with $\mathrm{NADH}$ and $\mathrm{NADPH}$, respectively [20]. It should be noted that their assay was conducted at $30^{\circ} \mathrm{C}$, while ours was conducted at $40^{\circ} \mathrm{C}$

\section{Conclusion}

The results indicate that IMB yeast have potential for biological xylitol production. IMB1 and IMB2 were the best xylitol producers $(\mathrm{p}<0.05)$. Xylitol production until $96 \mathrm{~h}$ was greatest at $40^{\circ} \mathrm{C}$, and from 96 to $144 \mathrm{~h}$ it was greatest at $45^{\circ} \mathrm{C}$. The greatest xylitol yield achieved from xylose was $0.90 \mathrm{~g} / \mathrm{g}$ with $\mathrm{IMB} 2$ at $40^{\circ} \mathrm{C}$ using $1.0 \mathrm{~g} / \mathrm{l}$ initial cell mass and $50 \mathrm{~g} / \mathrm{l}$ initial xylose concentration. Based on the present study, K. marxianus IMB2 was the most promising strain in this study for biological xylitol production with the following advantages: high product yields, no genetic modification, and a thermotolerant nature; however, productivity must be improved.

\section{Acknowledgements}

The authors would like to acknowledge the Oklahoma Agricultural Experiment Station for supporting this research.

\section{References}

1. Guo C, Zhao C, He P, Lu D, Shen A, et al. (2006) Screening and characterization of yeasts for xylitol production. J Appl Microbiol 101: 1096-1104.

2. Granstrom TB, Izumori K, Leisola M (2007) A rare sugar xylitol. Part I: the biochemistry and biosynthesis of xylitol. Appl Microbiol Biot 74: 277-281.

3. Lynch $\mathrm{H}$, Milgrom $P(2003)$ Xylitol and dental caries: an overview for clinicians. Journal of California Dental Association 31: 205-209.
4. Kinami Y, Kitagawa I (1969) Fluctuation of blood sugar, urine sugar and ketone body levels in surgical stress and application of xylitol. Shujutsu 23: 1487-1491.

5. Brown CL, Graham SM, Cable BB, Ozer EA, Taft PJ, et al. (2004) Xylitol enhances bacterial killing in the rabbit maxillary sinus. Laryngoscope 114: 2021-2024.

6. Aminoff C, Vanninen E, Doty T (1978) Xylitol-occurence, manufacture and properties. Oral Health 68: 28-29.

7. Sirisansaneeyakul S, Staniszewski M, Rizzi M (1995) Screening of yeasts for production of xylitol from D-xylose. J Ferment Bioeng 80: 565-570.

8. Sampaio FC, Chaves-Alves VM, Converti A, Passos FML, Coelho JLC (2008) Influence of cultivation conditions on xylose-to-xylitol bioconversion by a new isolate of Debaryomyces hansenii. Bioresource Technol 99: 502-508.

9. Sampaio FC, De Faveri D, Mantovani HC, Passos FML, Perego P, et al. (2006) Use of response surface methodology for optimization of xylitol production by the new yeast strain Debaryomyces hansenii UFV-170. J Food Eng 76: 376-386.

10. Sampaio FC, Mantovani HC, Passos FJV, de Moraes CA, Converti A, et al. (2005) Bioconversion of D-xylose to xylitol by Debaryomyces hansenii UFV-170: Product formation versus growth. Process Biochem 40: 3600-3606.

11. Cheng KK, Zhang JA, Ling HZ, Ping WX, Huang W, et al. (2009) Optimization of $\mathrm{pH}$ and acetic acid concentration for bioconversion of hemicellulose from corncobs to xylitol by Candida tropicalis. Biochem Eng J 43: 203-207.

12. Banat IM, Marchant R (1995) Characterization and Potential Industrial Applications of 5 Novel, Thermotolerant, Fermentative, Yeast Strains. World J Microb Biot 11: 304-306.

13. Banat IM, Nigam P, Marchant R (1992) Isolation of Thermotolerant, Fermentative Yeasts Growing at 52-Degrees-C and Producing Ethanol at 45-Degrees- $\mathrm{C}$ and 50-Degrees-C. World J Microb Biot 8: 259-263.

14. Wilkins MR, Mueller M, Eichling S, Banat IM (2008) Fermentation of xylose by the thermotolerant yeast strains Kluyveromyces marxianus IMB2, IMB4, and IMB5 under anaerobic conditions. Process Biochem 43: 346-350.

15. Smiley KL and Bolen PL (1982) Demonstration of D-Xylose Reductase and DXylitol Dehydrogenase in Pachysolen-Tannophilus. Biotechnol Lett 4: 607-610.

16. Chiang C, Knight SG (1960) Metabolism of D-Xylose by Moulds. Nature 188 $79-81$

17. Fritsche W (2002) Mikrobiologie, Spektrum Akademischer Verlag Heidelbeg Berlin.

18. Ligthelm ME, Prior BA, Dupreez JC, Brandt V (1988) An Investigation of D-(1 C-13) Xylose Metabolism in Pichia-Stipitis under Aerobic and Anaerobic Conditions. Appl Microbiol Biot 28: 293-296.

19. Yablochkova EN, Bolotnikova OI, Mikhailova NP, Nemova NN, Ginak AI (2004) The activity of key enzymes in xylose-assimilating yeasts at different rates of oxygen transfer to the fermentation medium. Microbiology 73: 129-133.

20. Dowe N, McMillan J (2001) SSF experimental protocols: lignocellulosic biomass hydrolysis and fermentation. LAP-008 NREL Analytical Procedure. National Renewable Energy Laboratory, Golden, $\mathrm{CO}$.

21. Sluiter A, Hames B, Ruiz R, Scarlata C, Sluiter J,et al. (2004) Determination of sugars, byproducts, and degradation products in liquid fraction process samples. LAP-014 NREL Analytical Procedure. National Renewable Energy Laboratory Golden, CO.

Submit your next manuscript and get advantages of OMICS Group submissions

Unique features:

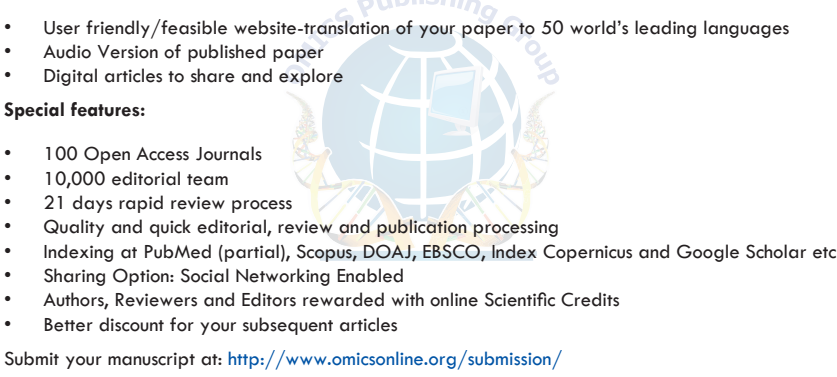

